\title{
Evaluation of The Antidepressant-like Effect of The Aqueous Extract of Prunus Mahaleb L. Seed kernels in Mice
}

\author{
Awatif M. Al-Saaedi \\ University of Thi-Qar/ College of Science/ Biology Department \\ Thi-Qar/Iraq \\ e-mail: awatifhistology_bio@sci.utq.edu.iq
}

https://doi.org/10.32792/utq/utjsci/v8/1/6

\begin{abstract}
Depression is a common psychiatric condition where $21 \%$ of the world population suffers from it. Prunus mahaleb is widely used in folk medicine to treat many diseases, but the antidepressant effect of this plant is not well investigated. The present study aims to evaluate the antidepressant-like activity of the aqueous extract of Prunus mahaleb seed kernels. For assessment of the antidepressant effect of aqueous extract of Prunus mahaleb at 200 and $400 \mathrm{mg} / \mathrm{kg}$, two models for depression were used in this study, forced swim test and tail suspension test. Aqueous extract of Prunus mahaleb seed kernels has a significant $(p<0.05)$ antidepressant-like effect at two doses 200 and $400 \mathrm{mg} / \mathrm{kg}$ in mice. Herbal medicine can play a significant role in treating depression; however, further studies are necessary to detect the pure compounds in Prunus mahaleb extract that responsible for the antidepressant activity and to understand their mechanism of action.
\end{abstract}

\section{Keywords-Depression, Prunus mahaleb, antidepressant}

\section{INTRODUCTION}

Depression is a common and disabling psychiatric condition, where $21 \%$ of the world population suffers from it. According to the reports of World Health Organization, mood disorders are the second leading cause of disabilityadjusted life years and also the leading cause of years lived with disability in different ages (Raymond, 2012; Kumar et al., 2014; Abdul Mannan, et al., 2015).

Unfortunately, some synthetic drugs used to treat depressed people have adverse effects, including fatigue, gastrointestinal or respiratory problems, anxiety, agitation, drowsiness, and cardiac arrhythmias besides the drug-drug interactions. These reasons create an opportunity for medicinal plants to use as alternative drugs for depression treatment (Talha et al., 2011).

Herbal therapies may be a successful way to treat depression since a large number of herbal preparations have appeared psychotherapeutic activities. The search for new pharmacotherapy from medicinal herbs and constituents isolated from plant extracts for psychiatric disorders, including depression, has advanced expressively over the previous decade (Zhang, 2004).

Prunus mahaleb L. (white mahaleb) is a member of Rosaceae family. This plant is native to the Mediterranean region. It is a tall shrub or a small tree up to $12 \mathrm{~m}$ in height. It produces a marginal fruit crop with cherry-like dark purple drupes and a very bitter taste. Culinary use of $P$. mahaleb seed kernels is restricted to the Southeastern part of Europe and West Asia (Oskoueian et al., 2012; Gerardi et al., 2016; Ravindran, 2017).

P. mahaleb has a great value in folk medicine to treat different diseases such as blood pressure, diarrhea, asthma, nausea, and kidney stone also it is used as a tonic for sensory organs and the heart and for relief of pain arising from liver and gastrointestinal troubles. Also, in Arabia, P. mahaleb kernels are used as a sedative (Shams and Schmidt, 2008; Oskoueian et al., 2012), but the antidepressant activity of $P$. mahaleb is not clearly investigated. The present study was designed to evaluate the antidepressant-like activity of the aqueous extract of $P$. mahaleb seed kernels in mice.

\section{MATERIALS AND METHODS}

\section{A. Plant material and extraction}

Dried $P$. mahaleb seed kernels were collected from the markets of Nasiriyah city in Thi-Qar province, south of Iraq, and were authenticated as $P$. mahaleb in the laboratories of University of Thi-Qar/ College of Science. Seed kernels were ground for the extraction process. Aqueous extract of P. mahaleb seed kernels was prepared according to the method of (Akomolafe et al., 2017) with some modification. Thirty grams of powdered seed kernels have to be soaked in $250 \mathrm{~mL}$ distilled water at $25 \pm 2{ }^{\circ} \mathrm{C}$ for $72 \mathrm{~h}$ in a beaker and was stirred by a magnetic bar and stirrer hot plate. Seed suspension was filtered with the help of Whatman No. 1 filter paper. The solvent was removed by rotary evaporator, and the obtained extract was dried at room temperature. The dried extract was stored at $4^{\circ} \mathrm{C}$ in a dark vial until the antidepressant activity was investigated. 


\section{B. Animals}

Forty two-month-old BALB/c mice (weighting about 2025 grams) of both sexes were purchased from the High Institute for Infertility Diagnosis and Assisted Reproduction Technologies, AL-Nahrain University/ Baghdad/ Iraq. The animals were housed and were maintained under standard hygienic conditions at $20^{\circ} \mathrm{C} \pm 2{ }^{\circ} \mathrm{C}$ with a 12 -hour day/night cycle and access to water and food ad libitum. Animals were treated in accordance with the Ethical Committee of College of Science/ Thi-Qar University.

\section{Antidepressant activity tests}

\section{1) Forced swimming test (FST)}

The FST was performed according to the method of (Porsolt et al., 1977). Twenty mice were divided into four groups ( $\mathrm{n}=5$ and were set to receive orally: group 1: distilled water (control), group 2: Imipramine Hydrochloride as a standard drug $(30 \mathrm{mg} / \mathrm{kg})$. group 3 and 4: $P$. mahaleb seed kernels extract $(200 \mathrm{mg} / \mathrm{kg})$ and $(400 \mathrm{mg} / \mathrm{kg})$ respectively, 1 $\mathrm{h}$. before the test. Mice were placed in an acrylic cylinder (30 $\mathrm{cm}$ height $\mathrm{x} 20 \mathrm{~cm}$ diameter) filled with water at $25 \pm 1{ }^{\circ} \mathrm{C}$ to a depth of $15 \mathrm{~cm}$ after $1 \mathrm{~h}$. of the treatment. All animals were forced to swim for $5 \mathrm{~min}$ and the duration of immobility (when they remained floating, motionless in the water, making only those movements necessary to keep its nose above water was observed and measured during the final 4 min. A significant decrease in the duration of immobility is an indicator of an antidepressant-like activity.

2) Tail suspension test (TST)

Twenty mice were also divided into four groups. They were treated orally with: Group 1: distilled water (control), group 2: $30 \mathrm{mg} / \mathrm{kg}$ Imipramine hydrochloride (standard), group 3 and 4: 200 and $400 \mathrm{mg} / \mathrm{kg}$ of $P$. mahaleb seed kernels respectively $1 \mathrm{~h}$. before the study. Mice were suspended on the edge of the table, $50 \mathrm{~cm}$ above the floor, with the help of adhesive tape placed approximately $1 \mathrm{~cm}$ from the end of the tail. The total duration of immobility induced by tail suspension was recorded by observation during the last $6 \mathrm{~min}$ of the $10 \mathrm{~min}$ period. The animal was considered to be immobile when it did not show any movement, hanged passively, and completely motionless (Steru et al., 1985).

\section{Statistical analysis}

The results are presented as mean \pm SEM. The statistical analysis was performed using one-way analysis of variance (ANOVA) followed by LSD post hoc test as appropriate using SPSS 14 software. Differences between groups were considered significant at a level of $\mathrm{p}<0.05$.

\section{RESULTS AND DISCUSSION}

The antidepressant-like effect of the aqueous extract of $P$. mahaleb seed kernels was illustrated in the table (1). The standard drug and also P. mahaleb extract at doses of 200 and $400 \mathrm{mg} / \mathrm{kg}$ produced a significant decrease in immobility time in the two models at $\mathrm{P}<0.05$ when compared with the control group.
TABLE (1): ANTIDEPRESSANT-LIKE EFFECT OF P. MAHALEB IN MICE.

\begin{tabular}{|c|c|c|c|}
\hline Groups & $\begin{array}{c}\text { Treatment } \\
\text { (orally) }\end{array}$ & $\begin{array}{c}\text { Forced Swim } \\
\text { test } \\
\text { Immobility } \\
\text { Duration } \\
\text { (Sec) }\end{array}$ & $\begin{array}{c}\text { Tail } \\
\text { suspension } \\
\text { test } \\
\text { Immobility } \\
\text { Duration } \\
(\mathrm{sec})\end{array}$ \\
\hline 1 & distilled water & $125.2000 \pm 4.95 \mathrm{a}$ & $155.22 \pm 1.88 \mathrm{a}$ \\
\hline 2 & $\begin{array}{c}\text { Imipramine } \\
\text { hydrochloride } \\
(30 \mathrm{mg} / \mathrm{kg})\end{array}$ & $55.4000 \pm 1.80 \mathrm{~b}$ & $63.80 \pm 1.77 \mathrm{~b}$ \\
\hline 3 & $\begin{array}{c}200 \mathrm{mg} / \mathrm{kg} \text { of } \\
\text { the extract }\end{array}$ & $55.6000 \pm 2.15 \mathrm{~b}$ & $91.61 \pm 2.65 \mathrm{c}$ \\
\hline 4 & $\begin{array}{c}400 \mathrm{mg} / \mathrm{kg} \text { of } \\
\text { the extract }\end{array}$ & $45.2000 \pm 1.88 \mathrm{c}$ & $82.20 \pm 3.397 \mathrm{~d}$ \\
\hline
\end{tabular}

Value are means \pm S.E.M. Different letters refer to a significant difference at $\mathrm{P}<0.05$

FST has not traditionally been considered as a consistently sensitive model for detecting selective serotonin reuptake inhibitor activity, while these antidepressants are generally active in the TST (Castagn et al., 2011; Kiranmayi et al., 2018).

The main biochemical causes of depression are metabolic disorders of monoamine neurotransmitters that are involved in noradrenaline, serotonin, and dopamine signaling (Naughton et al., 2000; Li et al., 2013).

The antidepressant activity of plant preparations was linked to their content of flavonoids and Coumarin because of their antioxidant effect. Hesperidin, Chrysin, Naringenin, and Astilbin are examples of flavonoids that have antidepressant activity ( Singh et al., 1992; Bubols et al., 2013; Guan and Liu, 2016; Hritcu et al., 2017).

Seed kernels of $\mathrm{P}$. mahaleb have a high content of coumarins (Ieri et al., 2012). This may be the cause of the antidepressant effect of the kernels extract in this study.

It could be concluded that the aqueous extract of $P$. mahaleb seed kernels has antidepressant-like activity; further studies are necessary to detect the pure compounds in $P$. mahaleb extract that responsible for the antidepressant activity and to understand their mechanism of action.

\section{REFERENCES}

1- Abdul Mannan, M.; Ariful, B. and Rashidur Rahman, M. (2015). Antidepressant-like Effects of Methanolic Extract of Bacopa Monniera in Mice. BMC Complementary and Alternative Medicine 15(1): 1-8.

2- Akomolafe, S.; Ganiyu, O.; Sunday, I. and Tosin, A. ( 2017). Toxicological Effects of Aqueous Extract From African Walnut (Tetracarpidium Conophorum) Leaves in Rats. Journal of Evidence-Based Complementary and Alternative Medicine. 22(4): 919925.

3- Bubols, G.; Vianna, D.; Medina-Remon, A.; von, P.; Lamuela-Raventos, R.; Eifler-Lima, V. and Garcia, S. 
(2013). The antioxidant activity of coumarins and flavonoids. Mini Rev Med Chem. 13(3):318-334.

4- Castagn, V.; Paul, M.; Sylvain, R. and Roger, D. (2011). Rodent Models of Depression : Forced Swim and Tail Suspension Behavioral Despair Tests in Rats and Mice. Current Protocols in Neuroscience. (April): 1-14. DOI: 10.1002/0471142301.ns0810as55.

5- Gerardi, C.; Stefania, F.; Leonardo, C.; Antonella, L.; Raffaella, L.; Nadia, C.; Maria, A.; Federica, B. and Giovanni, M. (2016). Anti-Proliferative, AntiInflammatory and Anti-Mutagenic Activities of a Prunus Mahaleb L. Anthocyanin-Rich Fruit Extract. Journal of Functional Foods .27: 537-548.

6- Guan, L-P. and Liu, B-Y. (2016). Antidepressantlike effects and mechanisms of flavonoids and related analogues. European Journal of Medicinal Chemistry. 121 (2016) : 47-57.

7- Hritcu, L.; Radu, I.; Paula, A.; Girish, K.; Hasan, T.; Tamires, C.; Caroline, U. and Damião, P. (2017). Antidepressant Flavonoids and Their Relationship with Oxidative Stress. Oxidative Medicine and Cellular Longevity. 2017. https://doi.org/10.1155/2017/5762172.

8- Ieri, F.; Patrizia, P. and Annalisa, R. (2012). Simultaneous Determination of Anthocyanins, Coumarins and Phenolic Acids in Fruits, Kernels and Liqueur of Prunus Mahaleb L. Food Chemistry 135(4): 2157-2162.

9- Kiranmayi, G.; Poojitha, R.; Bhavani, R.; Monika, S. and Kumar, S. (2018). Phytochemical Investigation, in vitro antioxidant, and in vivo antidepressant activity of ethanolic leaf extract Antigonon leptopus 12(1): 235-240.

10-Kumar, A.; Lakshman, K.; Velmurugan, C.; Sridhar, S. and Gopisetty, S. (2014). Antidepressant activity of methanolic extract of amaranthus spinosus. Basic Clin Neurosci. 5(1): 11-17.

11-Li, L.; Jie, Y.; Shi Ping, M. and Rong, Q. (2013). Magnolol Treatment Reversed the Glial Pathology in an Unpredictable Chronic Mild Stress-Induced Rat Model of Depression. European Journal of Pharmacology .711(1-3): 42-49.

12-Naughton, M.; Mulrooney, J. and Leonard, B. (2000). A Review of the Role of Serotonin Receptors in Psychiatric Disorders . Human Psychopharmacology. Hum Psychopharmacol Clin Exp. 15(6): 397-415.

13-Oskoueian, A.; Reza, S.; Mahmmod, E. and Ehsan, O. (2012). Bioactive Compounds, Antioxidant, Tyrosinase Inhibition, Xanthine Oxidase Inhibition, Anticholinesterase and Anti Inflammatory Activities of Prunus Mahaleb L. Seed. Journal of Medicinal Plants Research. 6(2): 225-533.

14-Porsolt, R.; Bertin, A. and Jalfre, M. (1977). Behavioral despair in mice: a primary screening test for antidepressants. Arch Int Pharmacodyn Ther.229:327-36.

15-Ravindran, P. (2017). The encyclopedia of herbs and spices. CABI. Uk. P. 129.

16- Raymond, W.. (2012). Depression. 2nd ed. Oxford University Press. Uk. P 1-6.

17- Shams, K. and Schmidt, R. (2008). Lipid Fraction Constituents and Evaluation of Anti-Anaphylactic Activity of Prunus Mahaleb Kernels. Afr. J. Traditional, Complementary and Alternative Medicines.4(3): 289-293.
18- Singh, V.; Srivastava, V.; Palit, G. and Shanker, K. (1992). Coumarin congeners as antidepressants. Arzneimittelforschung. 42(8):993-996.

19- Steru, L.; Raymond, C.; Bernard, T. and Pierre, S. (1985). The Tail Suspension Test: A New Method for Screening Antidepressants in Mice. Psychopharmacology. 85(3): 367-370.

20- Talha, J.; Roli, G. and Zohaib, A. (2011). A review on herbal plants showing antidepressant activity. International Journal of Pharmaceutical Sciences Review and Research. 2(12): 3051-3060.

21- Zhang, Z-J. (2004). Therapeutic Effects of Herbal Extracts and Constituents in Animal Models of Psychiatric Disorders. Life Sciences 75(2004): 1659-1699. 